\title{
The Effect of Peer Teaching Methods on Results of Learning Writing Negotiation Text
}

Munirah*, Fuput Sartika, Anin Asnidar, Akram Budiman Yusuf

Department of Indonesian Language and Literature Education, Postgraduate Program of Muhammadiyah University of Makassar. Sultan Alauddin St. No. 259, South Sulawesi, Indonesia

*Corresponding author: munirah@unismuh.ac.id

Article history: Received: 01 January 2020 Received in revised form: 09 February 2020 Accepted: 02 March 2020 Published online: 26 August 2020

\begin{abstract}
This study aims to determine the effect of peer teaching learning methods on learning outcomes of negotiating text writing skills. This study is a true experimental design study aimed to determine the effect of peer teaching learning methods on learning outcomes of the writing ability of negotiating students in class X MA Aisyiyah Sungguminasa 2018/2019 academic year. The research design used was a pretest-posttest control group design. The study population was all of MA Aisyiyah Sungguminasa students consisting of six classes. Samples were obtained using purposive sampling technique and selected Science class X as the experimental class and Social class X as a control class with the number of students respectively 24 and 29 students. The experimental class was taught using the peer teaching method, while the control class was without using the peer teaching method. The independent variable in this study is the peer teaching method, and the dependent variable is the learning outcome of students' negotiating writing ability. Data collection techniques used test techniques taken from the results of the posttest and observations of students' activities on the application of the method. Inferential statistical analysis results prove that the data are normally distributed and homogeneous. Hypothesis testing carried out by $t_{\text {-test }}$ resulted in a t-count of 872.5 which was then compared with a $\mathrm{t}_{\text {-table }}$ of 2.007 or $\mathrm{t}_{\text {-count }}>\mathrm{t}$-table which means that $\mathrm{H} 0$ was rejected and $\mathrm{H} 1$ was accepted. An alternative hypothesis (H1) is accepted if the value of $t_{\text {-count }}>t$-table. It can be concluded that the method of peer teaching affects the learning outcomes in the negotiation material of class X MA Aisyiyah Sungguminasa.
\end{abstract}

Keywords: Peer teaching methods, writing negotiating texts, Indonesian learning outcomes

(C) 2020 Penerbit UTM Press. All rights reserved

\subsection{INTRODUCTION}

In essence, learning is something that is conscious to know something. Learning is also an effort made by teachers for their students to get knowledges, characters and skills so they can be made ready for life in the future (Parwatiningsih, Ropitasari, \& Kartikasari, 2020). Therefore, teachers play an important role in determining appropriate learning methods to improve student learning outcomes (Suyono, 2011). Learning methods are all the planning and procedures as well as the steps of learning activities including the choice of assessment methods to be carried out. Learning methods can be considered as a procedure or an orderly way to conduct learning (Suyono, 2011).

The chosen learning method is expected to not only invite students to memorize the subject matter provided, but be able to encourage and construct the knowledge that has been obtained then connect that knowledge with its application in student life (Hadi \& Herawati, n.d.). A teacher must be able to design learning methods so as to be able to bring a learning atmosphere that can help improve student learning outcomes in learning (Gredler, 1992). In addition, the learning method is able to involve students fully in the learning process that is held, so that students are able to master the competencies taught and the competencies that exist in themselves. Some MA Aisyiyah Sungguminasa students are less enthusiastic in learning Indonesian, thus causing student learning outcomes to decline. Though learning Indonesian is not so difficult to learn. One reason is the learning methods used are less effective.

Learning systems that provide opportunities for students to actively carry out activities in the learning process and cause student learning outcomes to improve in learning a learning material, so that what students get from learning will be stored for a long time (Amri, 2013). Therefore, it is interesting to do it using learning methods that are easy to understand, fun, and attract students' attention to explore further learning resources, namely the Peer Teaching Learning Method (Santyasa, 2007). Peer Teaching Learning Method is a learning method that teaches active and independent students in a learning, not only focused on the teacher but students can play an important role in the ongoing learning process (Arjanggi \& Suprihatin, 2011). In this method students are divided into several groups, after that each student must understand each material provided by the teacher by providing a time period, when conducting discussions in each group, so that when it meets the given time period, each group representative comes to other groups and explain the material that students understand (Fitria, Mustangin, \& Nursit, 2019; Megawati, 2019). 
In the modern era, students are less enthusiastic and are reluctant to ask the teacher, whether it is due to shame or other factors, causing student learning outcomes to decline, therefore the teacher's role is needed in helping students in the course of learning (Damayanti \& Ariyanto, 2019; Parwatiningsih et al., 2020; Salim, Sumarwati, \& St Y, 2019; Sanjaya, 2015). The teacher plays an important role in developing an effective method in accordance with the material provided. In the negotiation material, the most effective method used is the peer teaching method, in the peer teaching method students play an active role in it, and if there are students who do not understand but are reluctant to ask the teacher, then the student can ask their peers directly (Siregar \& Nara, 2010). Nowadays most students are also easier and faster to understand the learning material when explaining the material is their peers, compared to the teacher (Taha, 2008).

Writing negotiating texts is one of the language competencies that students must master at school. This writing competence is essentially the same as competence in writing other texts such as narration, argumentation, description, or exposition. It's just that in writing negotiating texts, special skills are needed because there are other competencies that must be possessed by a writer that is putting the ability to influence others in the use of language. Therefore, writing a good negotiating text must be able to use words that can listen to the listener. The influence here is an interest and a willingness to accept the purpose of negotiation (Dewi, Suandi, \& Yasa, 2015; Patonah, Syahrullah, Firmansyah, \& San Fauziya, 2018). For this reason, teaching this material requires an accurate strategy to achieve the expected goals. Peer teaching is a method that is cured by involving peers as a mentor to other peers who have limitations in understanding concepts or subject matter (Febianti, 2014). With this method, students will learn to be teachers for other students. In addition to training students, the peer teaching method also has good abilities for students who find it difficult to solve lessons, because with this method students will share knowledge with other colleagues. This condition makes it easier for students to remember that the source material comes from people who are considered friends or peers (Assinder, 1991; Secomb, 2008). In solving skills, as well as speaking skills, peer teaching methods encourage effective learning to overcome student learning difficulties (Goldschmid \& Goldschmid, 1976; Nurmiati \& Mantasiah, 2017).

\subsection{RESEARCH METHODS}

This type of research employed an experimental research design to determine differences in student learning outcomes in negotiating material through the Peer Teaching learning method. True Experimental Design is the design that being used in this study. The form of this design is the Pretest-Posttest Control Group Design before being given the first treatment given a test (Sukmadinata, 2005). Then the subject is given treatment and finally given a test to see the presence or absence of treatment influence.

There are two variables in this study, namely the peer teaching method (independent variable) and the learning outcomes of writing negotiating text (the dependent variable). All students of class X MA Aisyiyah Sungguminasa in the 2018/2019 Academic Year as many as 53 students is population, with the sampling technique used was purposive sampling, ie the sample was determined by the researcher by taking into account research needs.

Data collection techniques that will be used, namely the learning outcomes test technique that aims to determine the level of student mastery of learning material collected using pretest and posttest at the beginning and end of learning. To find out the effect of applying the peer teaching method, researchers used a comparison of student learning outcomes data before and after the method was applied. This is done by using a test technique. The type of test used is multiple choice of 45 numbers. The grading system used with technical tests gives a score of one if the answer is correct and zero if the answer is wrong. Scores obtained by students are then converted to grades using the following formula. The data in this study were analyzed with a simple linear regression technique to determine the effect caused. The process of analyzing data using the SPSS program is done descriptively or inferentially.

\subsection{RESULTS AND DISCUSSION}

In the experimental class, namely X Science the learning process uses the peer teaching method, whereas in the control class, namely $\mathrm{X}$ Social does not use the peer teaching method. In the implementation of learning researchers act as instructors. All samples in this study, both in the control class and experimental class were involved in conducting the research. Posttest data results were obtained after the two classes received different treatment in learning Indonesian on negotiating material.

The data collected in this study was used to see the results of the second class research. In this study the number of face-to-face meetings was six times, the first meeting was pretest, the second to fifth meeting giving negotiation material with the experimental class using the peer teaching method and the control class did not use the peer teaching method, while the sixth meeting was held posttest. Before learning in class is carried out first, a pretest is used to determine the students' initial abilities in the negotiation material. In the implementation of the pretest the experimental class was attended by 24 students and the control class was attended by 29 students. After the pretest is then the researcher carries out learning with different treatments in the experimental class and also in the control class, then posttest is conducted to determine the discrepancies in learning outcomes between the two classes.

At the initial stage, before being given treatment, pretest is given to know the ability of the experimental class and the control class, after that it is given a posttest after being given treatment that is using the peer teaching method in the experimental class and not using the peer teaching method in the control class. From the posttest results the average value obtained in the experimental class was 74.20 , while in the control class the average value obtained was 60.24. This means that the effect of the peer teaching learning method on learning outcomes in the negotiation material that is applied in the experimental class is higher than in the control class that does not use the treatment of the peer teaching learning method. In addition, the number of students who reached the completeness criteria for learning outcomes in the experimental class was higher, namely 16 students with a percentage of quantity of $66.6 \%$, meanwhile there were 6 students with a percentage of quantity of $20.68 \%$ in the control class.

The effect of peer teaching learning methods on student learning outcomes can also be seen in the acquisition of N-Gain which shows that the value of learning outcomes in the two classes are much different ie the experimental class received better results than the control class. In the experimental class students who received N-Gain with a high category of $8.33 \%$, a medium category of $70.83 \%$, and for a low category of $20.83 \%$. Whereas the $\mathrm{N}$-Gain control class with a high category was $6.89 \%$, the medium category was $51.72 \%$, and for the low category it was $41.37 \%$. 
Student learning results in the experimental class that is 16 students get complete grades and 8 students who do not complete. In the control class 6 students get complete grades and 23 students who do not complete. The learning outcomes indicate a difference between the experimental class and the control class, the learning outcomes in the experimental class are higher due to the influence of the peer teaching learning method on student learning outcomes in the negotiation material. The difference in learning outcomes from the two classes provides a different picture given by the teacher in learning, which is a learning method that contributes greatly to the difference in learning outcomes. In other words the peer teaching method is better than the conventional method used by the teacher.

The use of peer teaching methods can improve student learning outcomes, because the peer teaching method can influence important aspects of learning outcomes, namely increasing student attention for learning. When students have paid attention to the lesson it means that there is a desire of students to know the material they are learning, so they are more eager to learn. The method of peer teaching and learning trains students to be tutors in delivering lessons to peers. The peer teaching method is the use of classmates to help spark learning enthusiasm and curiosity about the material being studied. Students tend to be ashamed to express problems experienced in the learning process of the teacher, but in their peers, students will try to help each other if they encounter problems while learning. Through the peer teaching learning method, students are expected to be able to actualize their ability to be more caring for their peers who are less capable and jointly responsible for learning, as well as to foster self-confidence and subsequently be able to improve student learning outcomes.

The acquisition of higher student learning outcomes in the experimental class is strengthened by the results of inferential statistical analysis calculations carried out for manually testing hypotheses. Before testing the hypothesis, testing the analysis prerequisites first. The results of the analysis prerequisite tests for the experimental class and the control class in general both show that the data are normally distributed and homogeneous. Because the data obtained are normally distributed and homogeneous, then proceed with hypothesis testing using t-test. Obtained that for learning outcomes tcount $=872.5$ with $\mathrm{df}=51$ which is likely to be consulted with a ttable at a significant level

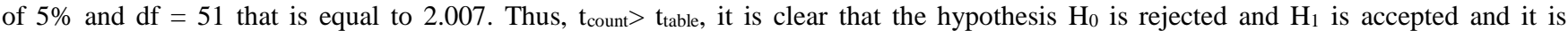
concluded that there is an influence of the use of peer teaching learning methods on learning to write negotiating text for class $\mathrm{X}$ MA Aisyiyah Sungguminasa.

\subsection{CONCLUSION}

Based on the results and discussion of the research, it was concluded that the method of peer teaching affects the learning of writing negotiating text for class X MA Aisyiyah Sungguminasa. This can be proven by increasing the average value of student learning outcomes in the experimental class 74.20, while the control class the average value of learning outcomes is 60.24 . T-test in this study is the $t_{\text {count }}$ of 872.5 with $\mathrm{df}=51$ which is then consulted with the value of $\mathrm{t}_{\text {table }}$ at $5 \%$ significance level and $\mathrm{df}=51$ which is equal to 2.007 . Thus, $\mathrm{t}_{\text {count }}>$ table which means $\mathrm{H}_{0}$ is rejected and $\mathrm{H}_{1}$ is accepted. So there is the effect of peer teaching learning methods on learning outcomes in the negotiation material for class X MA Aisyiyah Sungguminasa.

\section{References}

Amri, S. (2013). Pengembangan dan Model Pembelajaran dalam Kurikulum 2013. Jakarta: Prestasi Pustaka.

Arjanggi, R., \& Suprihatin, T. (2011). Metode Pembelajaran Tutor Teman Sebaya Meningkatkan Hasil Belajar Berdasar Regulasi-Diri. Hubs-Asia, 10(1), 91-97

Assinder, W. (1991). Peer teaching, peer learning: one model. ELT Journal, 45(3), 218 - 229.

Damayanti, N. E., \& Ariyanto, M. P. (2019). Pengaruh Pembelajaran Matematika dengan Herbart Method dan Peer Teaching Method Ditinjau dari Minat Belajar terhadap Hasil Belajar Peserta Didik Kelas XI di SMK Negeri 1 Selo. Universitas Muhammadiyah Surakarta.

Dewi, P. N. S., Suandi, I. N., \& Yasa, I. N. (2015). Implementasi pembelajaran menulis teks negosiasi berdasarkan kurikulum 2013 di kelas xb akuntansi SMK Negeri 1 Singaraja. Jurnal Pendidikan Bahasa Dan Sastra Indonesia Undiksha, 3(1), 1-12

Febianti, Y. N. (2014). Peer Teaching (Tutor Sebaya) Sebagai Metode Pembelajaran Untuk Melatih Siswa Mengajar. Edunomic Jurnal Pendidikan Ekonomi, 2(2), 80-87

Fitria, L., Mustangin, M., \& Nursit, I. (2019). Pemahaman Konsep Matematika dan Pemahaman Diri Peserta Didik Menggunakan Model Student Fasilitator Explaining Dengan Metode Peer Teaching. Jurnal Pendidikan Matematika (JPM), 5(2), 105-111.

Goldschmid, B., \& Goldschmid, M. L. (1976). Peer teaching in higher education: A review. Higher Education, 5(1), 9-33.

Gredler, M. E. (1992). Learning and instruction: Theory into practice. Macmillan New York.

Hadi, T., \& Herawati, I. (n.d.). S.(1990) Modul Pembelajaran Terpadu. Jakarta: Universitas Terbuka.

Megawati, E. (2019). Penggunaan Model Pembelajaran Peer Teaching dalam Pengajaran Tenses pada Mahasiswa EFL. DEIKSIS, 11(01), 39-50.

Nurmiati, N., \& Mantasiah, R. (2017). Keefektifan Penggunaan Metode Pembelajaran Tutor Sebaya (Peer-Teaching) Dalam Kemampuan Membaca Memahami Bahasa Jerman Siswa Kelas XI IPA SMA Negeri 1 Bontonompo Kabupaten Gowa. Eralingua: Jurnal Pendidikan Bahasa Asing Dan Sastra, 1(1), 54-62

Parwatiningsih, S. A., Ropitasari, R., \& Kartikasari, M. N. D. (2020). Pengaruh Metode Pembelajaran Praktikum Peer Teaching Terhadap Praktik Vulva Hygieni pada Mahasiswa DIII Kebidanan Fakultas Kedokteran Unhas. Jurnal Kebidanan Indonesia: Journal of Indonesia Midwifery, 11 (1), 90-97.

Patonah, S., Syahrullah, A., Firmansyah, D., \& San Fauziya, D. (2018). Pengaruh Model Pembelajaran Berbasis Masalah (Problem Based Learning) pada Pembelajaran Menulis Teks Negosiasi di Kelas X SMK Lentera Bangsa. Parole (Jurnal Pendidikan Bahasa Dan Sastra Indonesia), 1 (5), 807-814.

Salim, A., Sumarwati, S., \& St Y, S. (2019). Peningkatan Motivasi dan Keterampilan Menulis Eksplanasi dengan Menggunakan Metode Peer Teaching. MENDIDIK: Jurnal Kajian Pendidikan Dan Pengajaran, 5(1), 1-12.

Sanjaya, W. (2015). Perencanaan dan desain sistem pembelajaran. Jakarta: Kencana Prenadamedia Group.

Santyasa, I. W. (2007). Model-model pembelajaran inovatif. Universitas Pendidikan Ganesha.

Secomb, J. (2008). A systematic review of peer teaching and learning in clinical education. Journal of Clinical Nursing, 17(6), 703-716.

Siregar, E., \& Nara, H. (2010). Buku Ajar Teori Belajar dan Pembelajaran. Jakarta: UNJ.

Sukmadinata, N. S. (2005). Metode Penelitian Pendidikan. Bandung: Program Pascasarjana Universitas Pendidikan Indonesia dengan PT Remaja Rosdakarya.

Suyono, H. (2011). Belajar dan pembelajaran. Bandung: Remaja Rosdakarya.

Taha, Z. (2008). Gapura bahasa: kumpulan makalah pilihan tentang bahasa dan pengajaran bahasa. Badan Penerbit UNM. 